\title{
Use of the Free Gingival Grafting Technique for soft tissue reconstruction after excision of a Peripheral Ossifying Fibroma
}

\author{
Utilização da Técnica de Enxerto Gengival Livre para reconstrução de tecido mole após excisão de \\ um Fibroma Ossificante Periférico \\ Uso de la Técnica de Injerto Gingival Libre para la reconstrucción de tejidos blandos tras la \\ escisión de un Fibroma Osificante Periférico
}

Received: 02/02/2021 | Reviewed: 02/07/2021 | Accept: 02/12/2021 | Published: 02/19/2021

\author{
Nathalia Januario de Araujo \\ ORCID: https://orcid.org/0000-0003-1812-7723 \\ Universidade Estadual Paulista, Brasil \\ E-mail: nathaliajanuario56@gmail.com \\ Lara Brandão Ribeiro Franco \\ ORCID: https://orcid.org/0000-0001-9326-8679 \\ Universidade Estadual Paulista, Brasil \\ E-mail: larabrfranco@gmail.com \\ Leonardo Alan Delanora \\ ORCID: https://orcid.org/0000-0002-3002-4420 \\ Universidade Estadual Paulista, Brasil \\ E-mail: leonardoaland@gmail.com \\ Ruan Henrique Delmonica Barra \\ ORCID: https://orcid.org/0000-0002-7929-1618 \\ Universidade Estadual Paulista, Brasil \\ E-mail: ruan_d.barra@hotmail.com \\ Juliano Milanezi de Almeida \\ ORCID: https://orcid.org/0000-0002-5995-5747 \\ Universidade Estadual Paulista, Brasi \\ E-mail: jumilanezi@hotmail.com
}

\begin{abstract}
The Peripheral Ossifying Fibroma is a benign tumor that develops from a hyperplastic tissue reaction, usually related to traumatic stimulus that are responsible for triggering inflammatory reactions of the connective tissue. Histologically, it is a nodular mass characterized by a dense connective tissue, surrounded by stratified squamous epithelium. Surgical removal in these cases is indicated, and for reconstruction of soft tissue in the region, some periodontal surgical techniques are recommended, such as free gingival grafting. Thus, the present study aims to report a clinical case submitted to the free gingival graft technique for tissue reconstruction after the surgical removal of a fibroma. A total excision of the lesion was performed, later sent to a histopathological report where it was diagnosed as Peripheral Ossifying Fibroma, after the removal of the lesion the region was left with the periosteum exposed and then the free gingival graft was performed to cover the region and promote keratinized gum augmentation. This technique proved to be efficient for reconstruction of soft tissue in the region after surgical removal of the Peripheral Ossifying Fibroma, returning aesthetics, function and periodontal health.
\end{abstract}

Keywords: Fibroma; Combined therapy; Aesthetics.

\section{Resumo}

O Fibroma Ossificante Periférico é tumor benigno que se desenvolve a partir de uma reação hiperplásica tecidual, habitualmente relacionada a estímulos traumáticos que são responsáveis por desencadear reações inflamatórias do tecido conjuntivo. Histologicamente, é uma massa nodular caracterizada por um tecido conjuntivo denso, circundado por epitélio escamoso estratificado. A remoção cirúrgica nestes casos é indicada, e para reconstrução de tecido mole na região, algumas técnicas cirúrgicas periodontais são indicadas, como o enxerto gengival livre. Assim, o presente estudo tem como objetivo relatar um caso clínico submetido à técnica de enxerto gengival livre para reconstrução tecidual após a remoção cirúrgica de um fibroma. Foi realizada a excisão total da lesão, posteriormente enviado para laudo histopatológico onde foi diagnosticada como fibroma, após a remoção da lesão a região ficou com o periósteo exposto e então foi realizado o enxerto gengival livre para recobrir a região e promover aumento de gengiva queratinizada. Esta técnica se mostrou eficiente para reconstrução do tecido mole na região após a remoção cirúrgica do fibroma. Devolvendo estética, função e saúde periodontal. 
Palavras-chave: Fibroma; Terapia combinada; Estética.

\section{Resumen}

El fibroma osificante periférico es un tumor benigno que se desarrolla a partir de una reacción tisular hiperplásica, generalmente relacionada con estímulos traumáticos que son responsables de desencadenar reacciones inflamatorias del tejido conectivo. Histológicamente, es una masa nodular caracterizada por un tejido conectivo denso, rodeado de epitelio escamoso estratificado. La extirpación quirúrgica en estos casos está indicada, y para la reconstrucción de los tejidos blandos de la región, están indicadas algunas técnicas quirúrgicas periodontales, como el injerto gingival libre. Así, el presente estudio tiene como objetivo informar de un caso clínico sometido a la técnica del injerto gingival libre para la reconstrucción de tejidos tras la extirpación quirúrgica de un fibroma osificante periférico. Se realizó una escisión total de la lesión, posteriormente se envió a informe histopatológico donde se diagnosticó como fibroma, tras la extirpación de la lesión se dejó la región con el periostio expuesto y posteriormente se realizó el injerto gingival libre para cubrir la región y promover el agrandamiento gingival queratinizado. Esta técnica demostró ser eficaz para la reconstrucción de los tejidos blandos de la región tras la extirpación quirúrgica del fibroma, com la de volución de la estética, la función y la salud periodontal.

Palabras clave: Fibroma; Terapia combinada; Estética.

\section{Introduction}

Reactive hyperplastic lesions of the oral cavity (RHLOC) are developed essentially through chronic irritation or trauma, inducing a tissue response. They are relatively common, having their general appearance as a fibrous or flaccid, reddish, sessile or pediculated growth, and the gingiva being the most prevalent affected region (Dutra, Longo, Grando \& Rivero, 2019). As for the triggering factors, these lesions may occur due to systemic diseases, drug use, iatrogenic factors and the presence of uncontrolled biofilm (Hutton, Haveman, Wilson, \& Gonzalez-Torres, 2016). Nowadays, the RHLOC are Oral Pyogenic Granuloma, Inflammatory Fibrous Hyperplasia, Giant Cell Fibroma, Peripheral Giant Cell Lesions and Peripheral Ossifying Fibroma (Neville, 2011).

Regarding the epidemiological characteristics, the incidence of cases is presented predominantly by Fibrous Inflammatory Hyperplasia (72\%), followed by Piogenic Granuloma (12\%), Fibroma (7\%), Peripheral Ossifying Fibroma (5\%) and finally, Giant Cell Peripheral Granuloma (4\%). Besides, there is a higher general predilection for the female sex (74.19\%) the gingiva corresponds to the most affected region, since there is more accumulation of biofilm and exposure to irritant agents when compared to other intraoral sites, and often presents painlessly, or when they have symptoms, a slight bleeding, with radiographic findings usually absent (Dutra, et al., 2019).

These lesions represent a challenging diagnosis, as they could be confused with several clinical manifestations of similar characteristics, such as variations of anatomical structures, cysts, neoplasms and developmental abnormalities (Esmeili, Lozada-Nur, \& Epstein, 2005). Thus, the histopathological examination is essential to conclude the case.

The Peripheral Ossifying Fibroma (POF) a is clinically characterized as a fibrous nodular mass that presents exclusively in gingiva (Hutton, et al., 2016), with coloration varying from red to pink, usually originating from the interdental papilla. In addition, it is an asymptomatic lesion and may be present in the oral cavity for months until it is discovered (Neville, 2011). As for the specific epidemiological characteristics, POF has a prevalence of $60 \%$ in women and among individuals aged 10-29 years (Hutton, et al., 2016). As histopathological aspects fibroblasts proliferation is observed related to the formation of a mineralized material, which may consist of cementoid material, dystrophic calcifications or bone itself. In some cases, the lesion may have ulcerated areas, and so present a zone of granulation tissue under fibropurulent membrane (Neville, 2011).

The recommended choice for FOP treatment is excision biopsy with subperiostal depth, since the lesion has an expressive percentage of recurrence, with studies pointing between 7\% and 45\% (Hutton, et al., 2016 and Tezci, Meseli, Karaduman, Dogan, \& Meric, 2015). These approaches can cause a mucogingival defect, which makes necessary the repair through the use of surgical techniques such as positioned flaps, the connective tissue graft and the free gingival graft (Neville, 2011). 
Thus, the purpose of this study was to report a clinical case submitted to the free gingival graft technique for tissue reconstruction after surgical removal of a peripheral ossifying fibroma.

\section{Methodology}

This study is a case report in a qualitative and descriptive way, related to the clinical case presented of A 42-year-old male non-smoking patient, with an asymptomatic lesion with slow evolution 22 years ago that was accompanied by the periodontics team at the Faculty of Dentistry of Araçatuba - UNESP. The Informed Consent Form was signed by the patient, following all protocols under the same consent form (Pereira et al. 2018).

\section{Case Report}

A 42-year-old male non-smoking patient, without the use of controlled medication and without systemic alterations, arrived at the Araçatuba School of Dentistry - UNESP with a complaint of unfavorable aesthetics. During his anamnesis, the patient reported that he discovered an asymptomatic lesion with slow evolution 22 years ago, and then came to the university to remove it for aesthetic reasons. During the extraoral clinical examination, no significant alterations were found, neither lifoadenopathies. During intraoral clinical examination a single nodular lesion was observed, with $10 \mathrm{~mm}$ in its largest diameter, pale pink coloration, smooth surface, regular contour, clear limits, fibrous consistency, located in the gingival margin of teeth 33 and 34 (Figure 1 and 2). Regarding the periodontal clinical examination, the presence of periodontal pockets was not observed. Therefore, an excision biopsy of the lesion associated to the free gingival graft was chosen as the conduct.

Figure 1. Clinical appearance of the lesion.

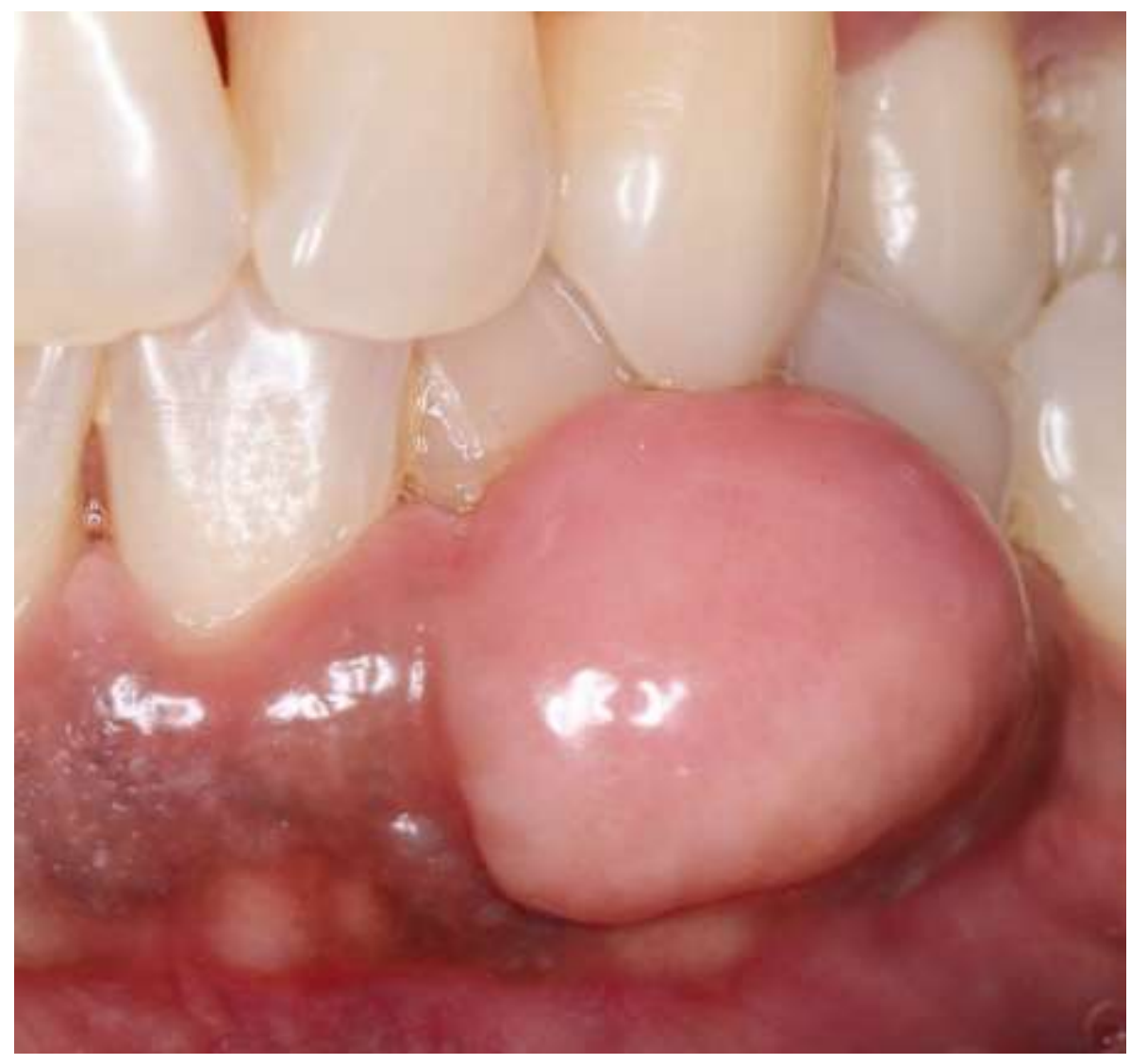

Source: Personal archive. 
The image shows the presence of a pale pink colored nodule, with well-defined limits and smooth surface, measuring approximately $10 \mathrm{~mm}$ in its largest diameter, in the left side region, between the canine and the first lower premolar.

Figure 2. Clinical appearance of the lesion.

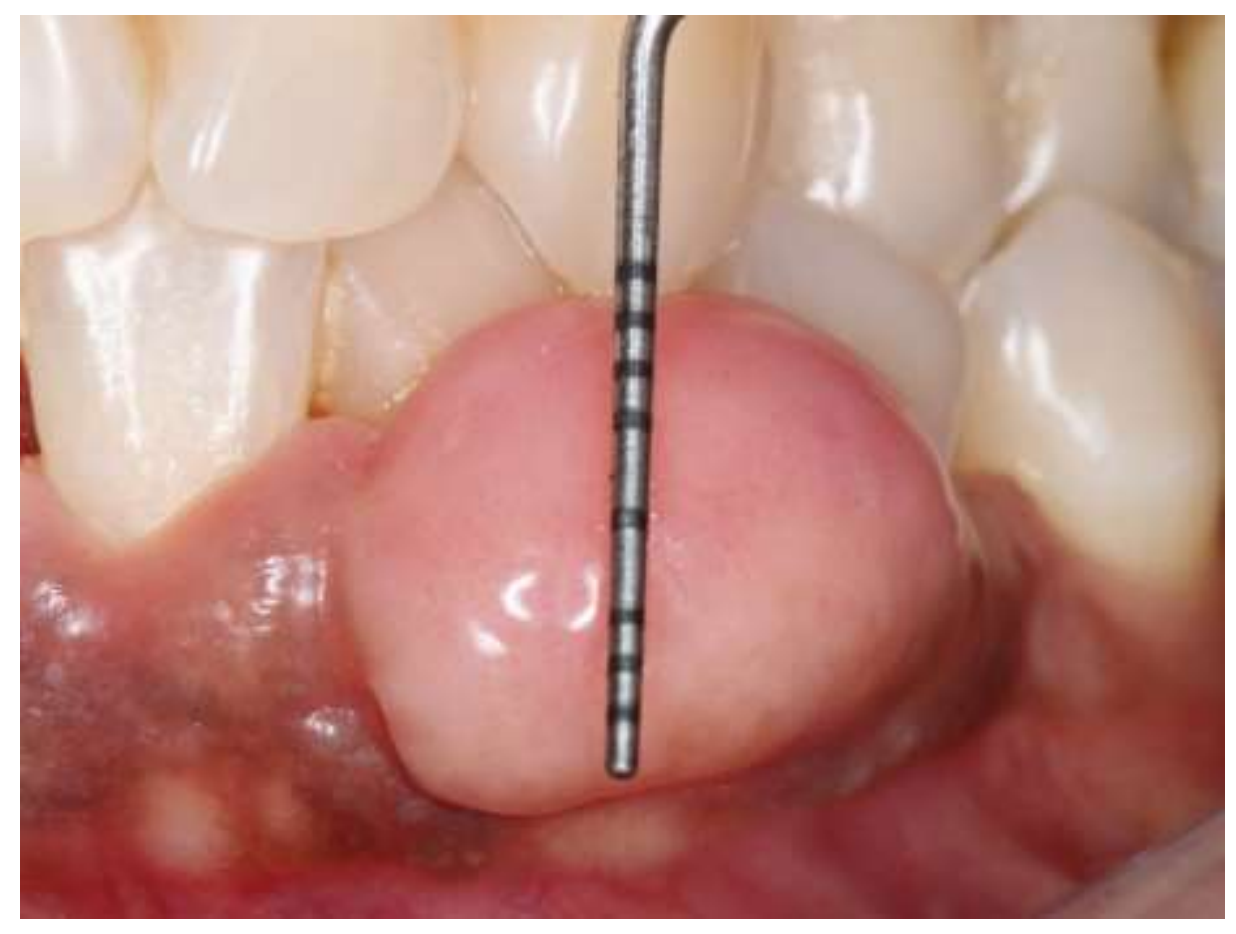

Source: Personal archive

The image illustrates the measurement of the lesion through the presence of the millimetered probe. You can see the confirmation of the size of $10 \mathrm{~mm}$.

Previously to the surgical procedures, the patient underwent basic periodontal therapy: scaling and root planing, as well as control and oral hygiene instructions. The surgical procedure was performed under local anesthesia with mepivacaine 2\% associated with epinephrine, at a concentration of 1: 100,000 (Nova DFL, Indústria e Comércio S.A, Rio de Janeiro, Brazil). The removal of the lesion, with a scalpel blade $n^{\circ}$ 15C (Swann-Morton, Sheffield, England), was performed including adjacent areas, to establish a safety margin (Figure 3). The lesion was then stored in $10 \%$ formaldehyde and forwarded for histopathological report. 
Figure 3. Removed lesion ready to be stored in $10 \%$ formaldehyde.

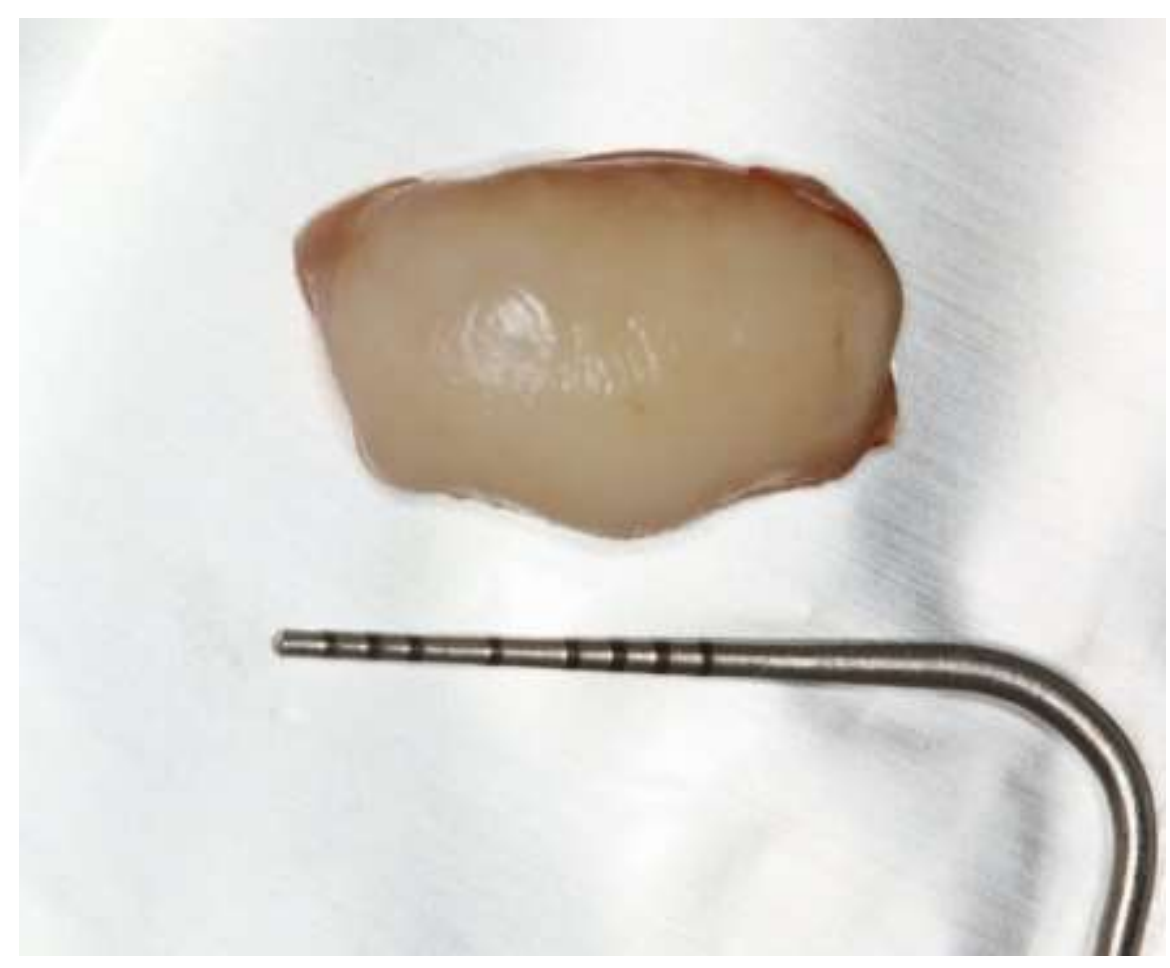

Source: Personal archive

The image shows the lesion completely extracted through the excisional biopsy, positioned in a gauze embedded with saline solution. Then, the lesion was submitted to inclusion in buffered formalin solution and sent for histopathological examination.

After the preparation of the receiving bed, a sterile paper mold was made with the dimensions found in the receiving area. The mold was then positioned on the palate and outlined with the scalpel blade. After the markings, the incisions were made, with a depth of approximately $1.5 \mathrm{~mm}$. Compressive sutures were performed with suture thread (Seda 4-0, Procare) in the donor area after the removal of the graft in order to stabilize the blood clot (Figure 4). 
Figure 4. Receiving area after removal of the lesion.

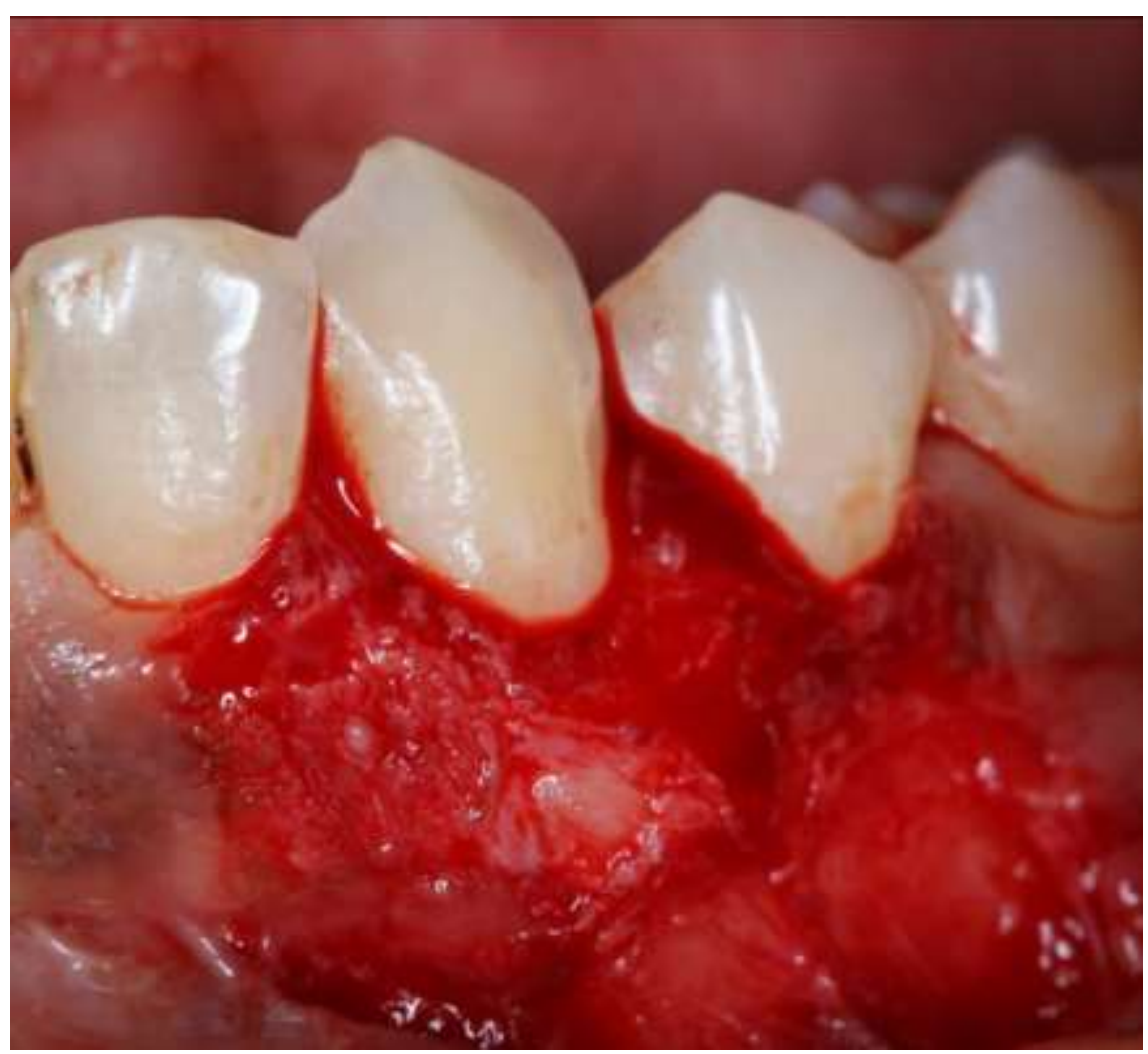

Source: Personal archive

The image shows the graft receiving area, after the excisional biopsy of the lesion.

The graft was placed on a sterile gauze soaked in saline solution and then with scalpel blade ${ }^{\circ} 15$ the remaining fat tissue was removed and discarded. After this procedure, the piece was already prepared for positioning on the recipient area. Immediately, the graft was placed over the recipient area, being performed lateral interrupted sutures for fixation and vertical compressive sutures, around the dental elements, to stabilize the piece (Figure 5). The surgical areas received surgical cement for 7 days, for protection. 
Figure 5. Donor area after compressive sutures.

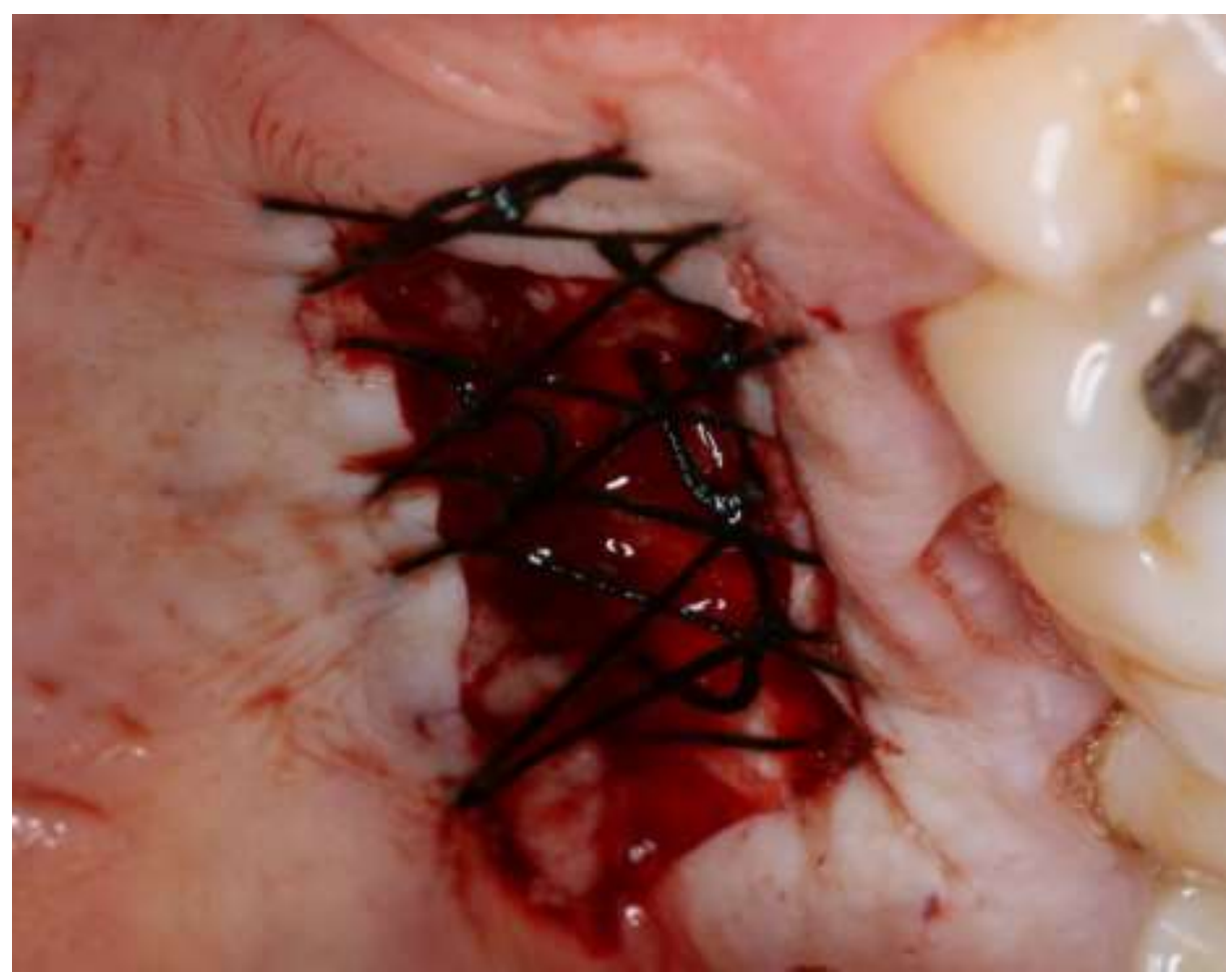

Source: Personal archive

The image shows the donor area, after performing the sutures, which were performed in purpose of stabilizing the clot.

As for postoperative care, the patient was guided to make ice packs on the face during the first hours. Amoxicillin 500 mg was prescribed every 8 hours for seven days, Nimesulide $100 \mathrm{mg}$ every 12 hours for three days, Dipyrone sodium 500 $\mathrm{mg} / \mathrm{ml}$ every 6 hours for two days in case of pain, in addition to making cheeks with $15 \mathrm{ml}$ of chlorhexidine digluconate $0.12 \%$ twice a day for seven days. The result of the histopathological report was received, with the results confirming the diagnosis of POF (Figure 6). During the return visits for follow-up, the importance of oral hygiene in the control of recurrence of the lesion was again oriented. 
Figure 6. Histological analysis of the lesion.

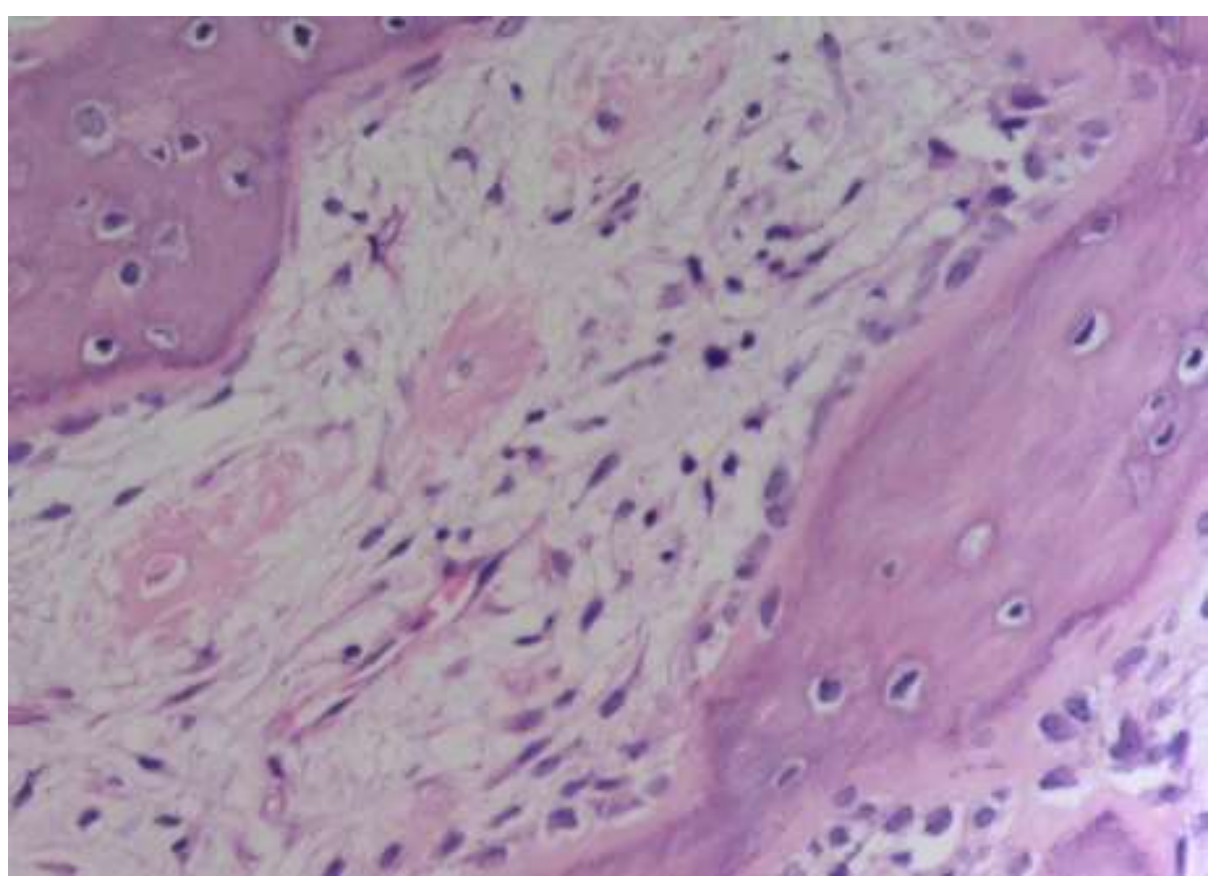

Source: Personal archive.

In Figure 6, it is possible to observe the fibroblasts proliferation is related to the formation of a mineralized material, which may consist of cementoid material, dystrophic calcifications or bone itself.

\section{Post-Operative Considerations}

Healing was observed within normality, with the absence of adverse events. It was also noted the absence of inflammatory reaction exacerbated with direct association to the surgical procedure. At seven days, it was observed that both receptor and donor beds were in a clear healing process, with some points of inflammation expected (Figures 7 and 8). At thirty days, the areas that received the surgical procedure were in a state of complete healing, with periodontal health, without recurrence of the lesion (Figure 9). The patient reported a significant improvement in biofilm control, besides not presenting any complaint regarding the area sensitivity, as well as satisfaction with the result from the aesthetic point of view. 
Research, Society and Development, v. 10, n. 2, e36710212622, 2021

(CC BY 4.0) | ISSN 2525-3409 | DOI: http://dx.doi.org/10.33448/rsd-v10i2.12622

Figure 7. 7-day post-operative in the receiving area.

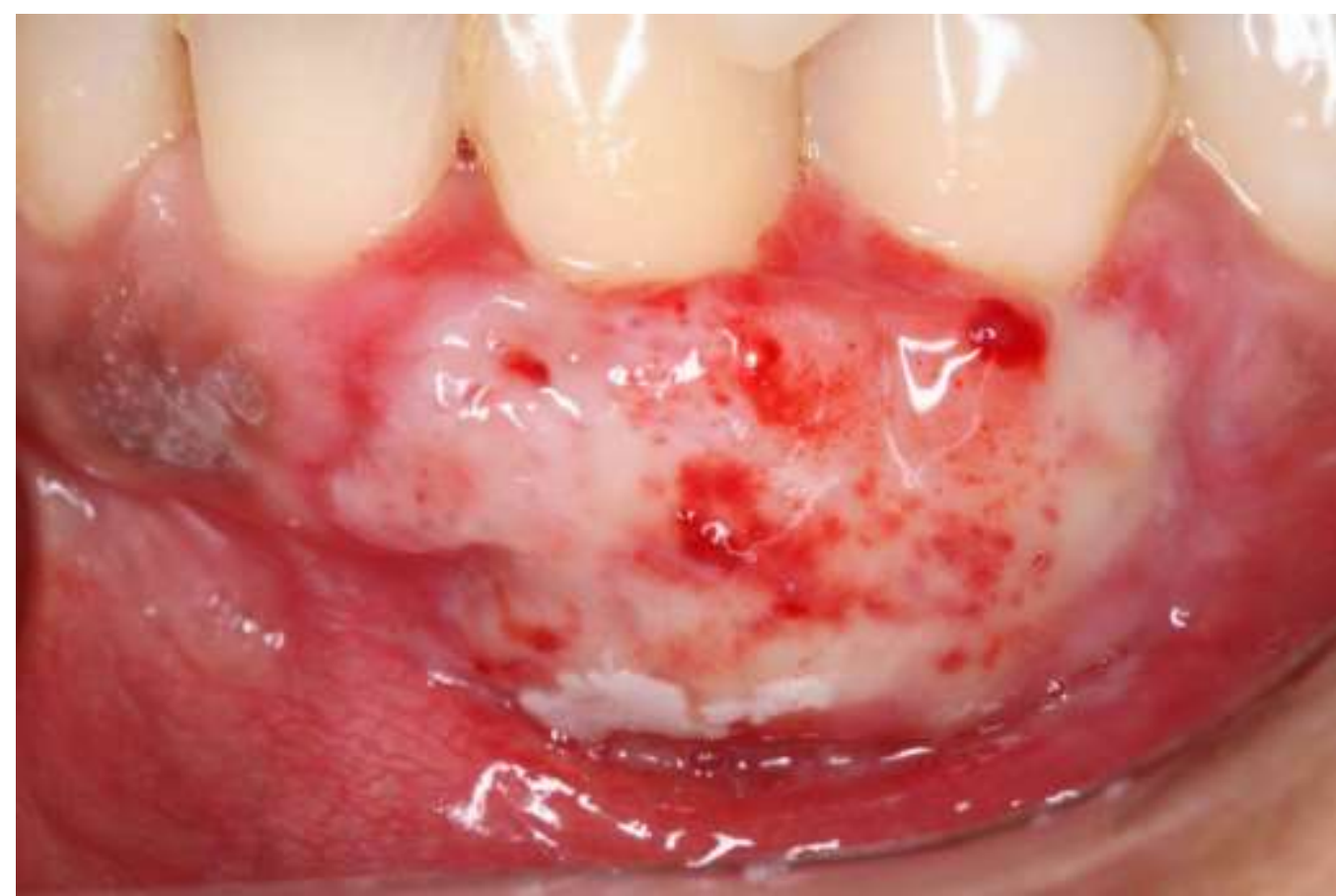

Source: Personal archive

The image shows the receiving area with the graft already in the healing process on the 7th day. The angiogenesis is observed, which indicates that the graft was successful. No evidence of an infectious process was noted.

Figure 8. 7-day post-operative in the donor area.

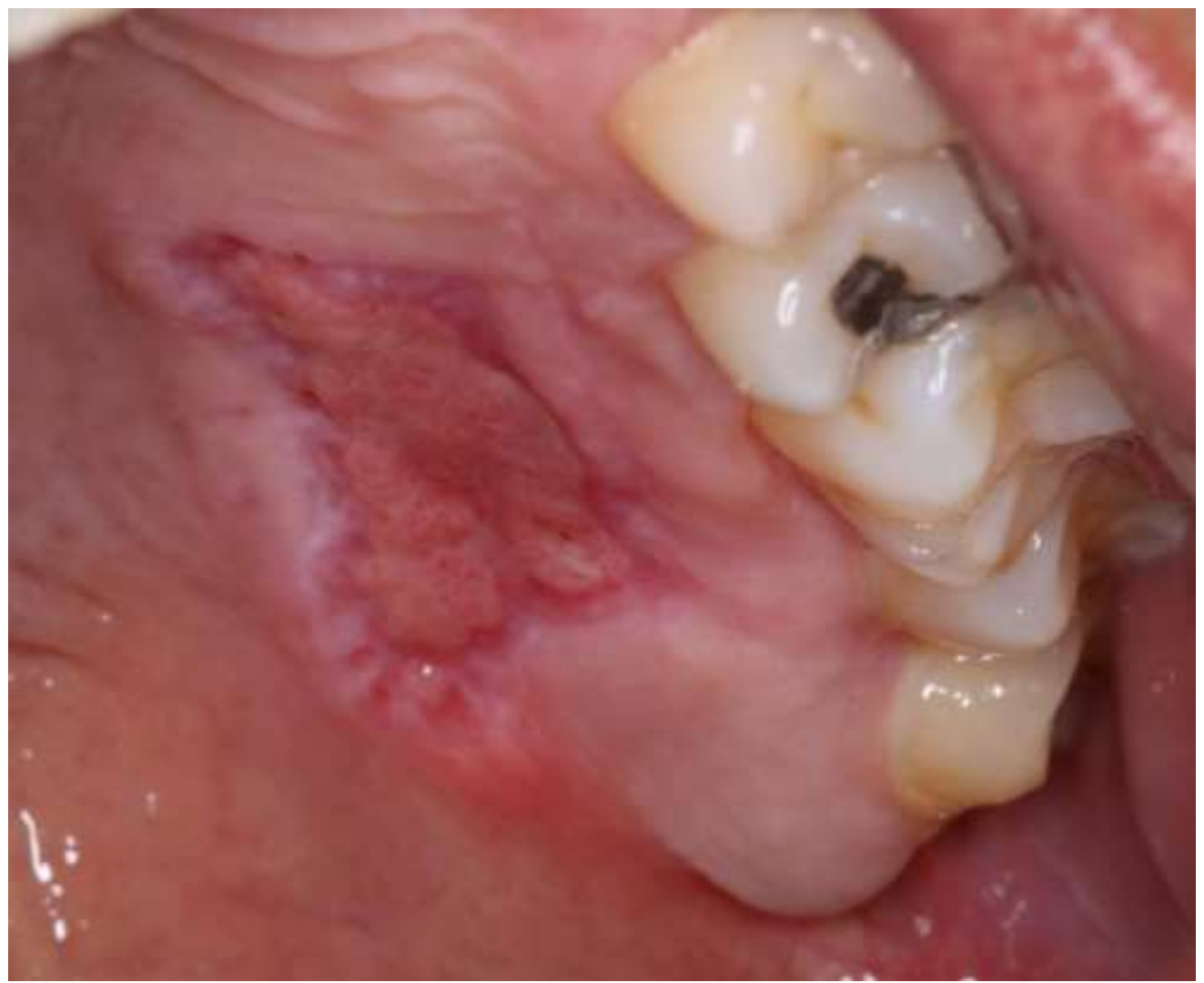

Source: Personal archive 
Research, Society and Development, v. 10, n. 2, e36710212622, 2021

(CC BY 4.0) | ISSN 2525-3409 | DOI: http://dx.doi.org/10.33448/rsd-v10i2.12622

The image shows the donor area on its 7th day after surgery, with evidence of a good healing process.

Figure 9. 30-day post-operative period in the receiving area.

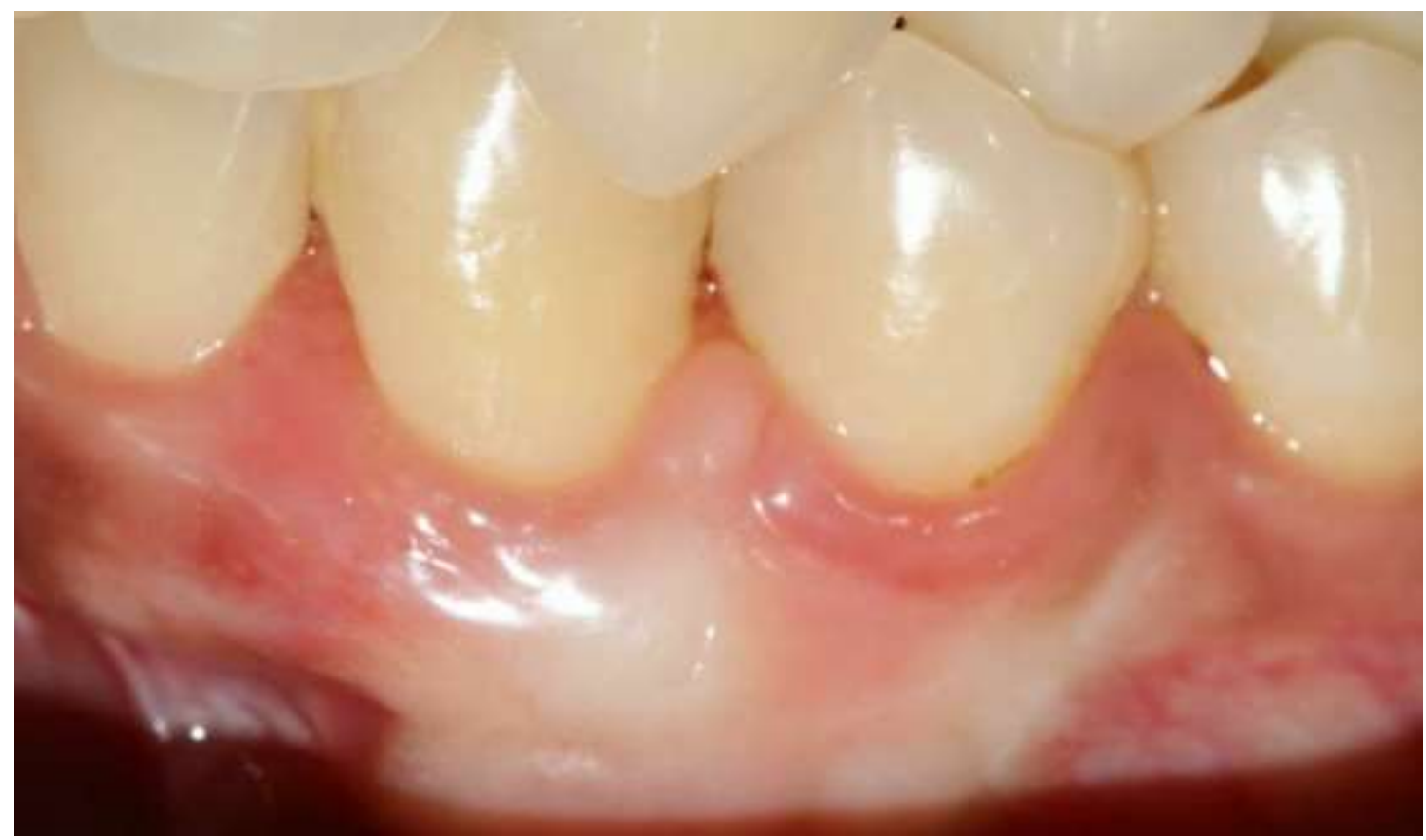

Source: Personal archive

The image shows the receiving area on its 30th day after the surgery, where the complete healing of the area and successful graft adaptation can be observed. 
Figure 10. 30-day post-operative period in the donor area.

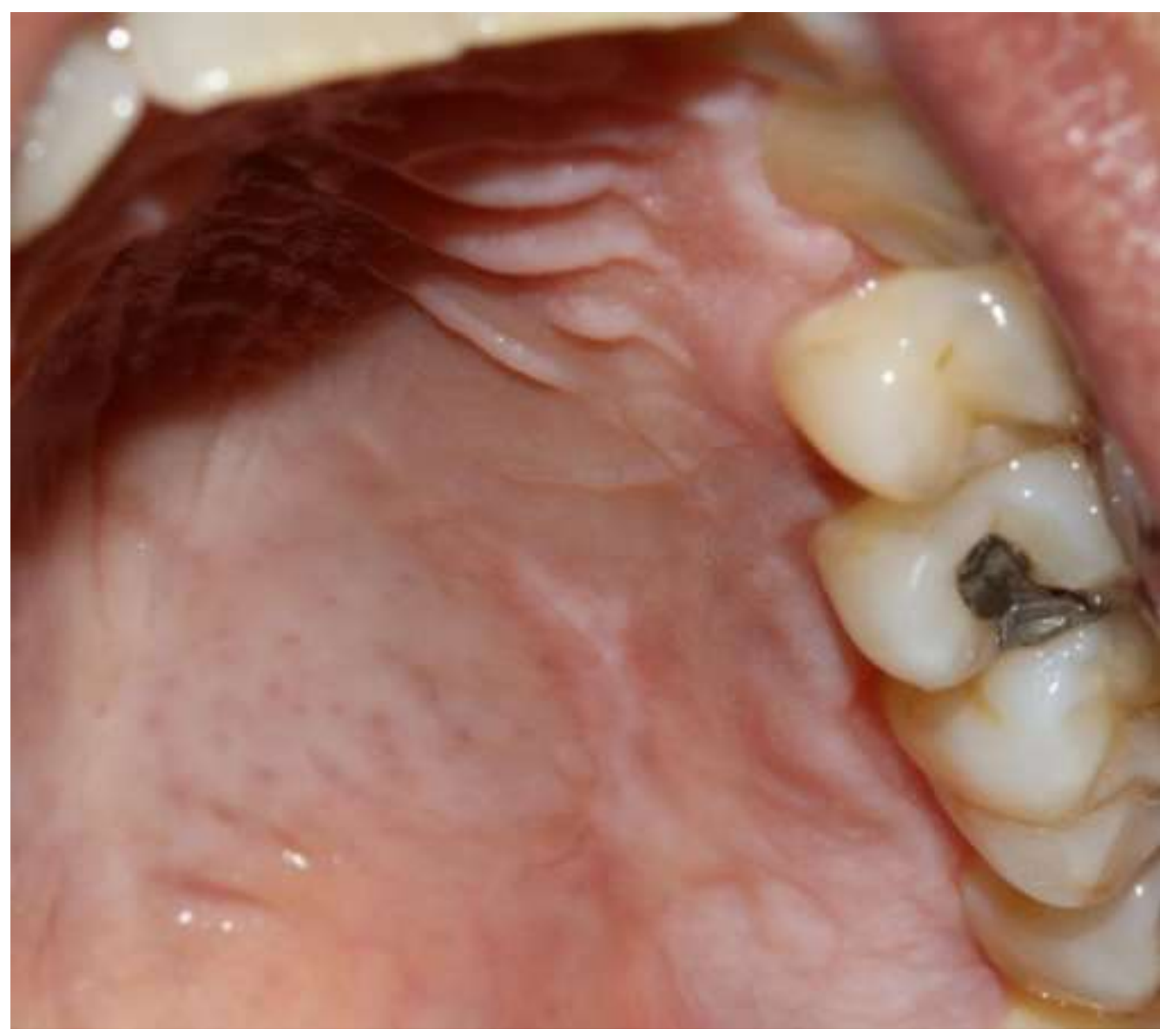

Source: Personal archive

The image shows the donor area on its 30th day after surgery, where the complete healing of the area is observed, with the total recovery of the removed tissue area.

\section{Discussion}

It is imperative that the detection and treatment of RHLOC be fast and assertive in order to reduce the probability of dento-alveolar complications as well as malignant changes (Tezci, Meseli, Karaduman, Dogan \& Meric, 2015) The differential diagnosis of POF is pyogenic granuloma and peripheral granuloma of giant cells, obtained only through histological analysis; with the main characteristics being stratified parakeratinized epithelium, with the presence of connective tissue in areas of bone formation accompanied by bundles of collagen distant from bone, with minimal inflammation (Zain \& Fei, 1990).

The recurrence of POF after conservative excision biopsy is between $16 \%$ and $20 \%$ of cases (Keskiner, Alka \& Tasdemir, 2016 and Walters, Will, Hatfield, Cacchillo \& Raabe, 2001). Thus, it is widely recommended in the literature to remove the lesion with safety margins up to bone level in order to minimize this probability (Henriques, Okajima, Nunes \& Montalli, 2016 and Bosco, Bonfante, Luize, Bosco \& Garcia, 2006). However, this more aggressive removal can cause a mucogingival defect, which besides representing an aesthetic deficiency, can also be a place more prone to trauma and biofilm accumulation, leading to other pathologies such as caries, recession and dental sensitivity (Keskiner, et al., 2016 and Walters, et al., 2001). Therefore, the correction of this defect is primordial for the success of the treatment.

As treatment alternatives for root recovering, the literature indicates several surgical techniques, highlighting the lateral displaced flap, the coronary displaced flap, the connective tissue graft and the free gingival graft, the method of choice 
being closely related to the amount of area to be recovered (Keskiner, et al., 2016 and Henriques, et al.,2016). In the reported case, the extension of the surgical bed after the lesion excision led to the choice of using the free gingival graft technique.

The Free Gingival Graft (FGG) is initially indicated for the purpose of increasing the keratinized gingiva range, and has often been recommended for covering exposed root surface (Tezci, et al.,2015 and Alves, Costa, Novaes Junior, Palioto, Taba Junior, Souza \& Grisi, 2012) he root covering after the surgical procedure cannot be estimated only by the insertion obtained in the first month after the surgery, because there is accentuated coronary migration within the grafted tissue within one year, which consists of the phenomenon called creeping attachment (Alves, et al., 2012). In addition, it can be cited as an advantage of the technique the ability to collect a larger area of donor tissue, and the graft can be used for greater coverage and thus treat multiple teeth (Carnio, Camargo \& Pirih, 2015). The EGL is also a simple and fast technique that shows superior or similar results in gingival enlargement when compared to other mucogingival surgical techniques (Tezci, et al.,2015 and Alves, et al., 2012).

Concerning the limitations and complications, EGL may present changes in gum color, since this technique tends to promote a scar-like repair, representing an aesthetic challenge. A second inconvenience is postoperative morbidity, since patients submitted to these procedures usually need more post-operative medications over a longer period than other techniques, because the donor area becomes unprotected after the surgical procedure (Alves, et al., 2012 and Carnio, et al., 2015).

In the present study, EGL was chosen due to the need of covering the expressive mucogingival defect, where the use of other surgical techniques would not be indicated. Thus, the predictability of success in treatment with the EGL technique is superior to the limitations found in the literature. In agreement with other studies in the literature (Keskiner, et al., 2016 and Henriques, et al.,2016), both the excisional biopsy and the free gingival graft occurred in the same clinical session. This decision was important to avoid exposing the patient to two uncomfortable postoperative periods, in addition to less exposure to emotional stress and time savings for the patient and the professional. Moreover, since it is a lesion caused by inflammatory reaction, it is essential to maintain oral hygiene with the elimination of etiological agents such as calculus, biofilms and mechanical traumas (Henriques, et al.,2016).

\section{Conclusion}

In this way, the use of the free gingival graft technique was favorable for the repair of the periodontal lining tissues after the lesion was removed, favoring the aesthetics and periodontal health. It is important to eliminate etiological factors to avoid recurrences, as well as a long-term post-operative follow-up.

\section{References}

Alves, L. B., Costa, P. P., Novaes Junior, A. B., Palioto, D. B., Taba Junior, M., Souza, S. L. S. D., \& Grisi, M. F. D. M. (2012). Enxerto gengival livre e retalho posicionado coronariamente para recobrimento radicular. Perionews, 409-415.

Bosco, A. F., Bonfante, S., Luize, D. S., Bosco, J. M. D., \& Garcia, V. G. (2006). Periodontal plastic surgery associated with treatment for the removal of gingival overgrowth. Journal of periodontology, 77(5), 922-928.

Carnio, J., Camargo, P. M., \& Pirih, P. Q. (2015). Surgical techniques to increase the apicocoronal dimension of the attached gingiva: a 1-year comparison between the free gingival graft and the modified apically repositioned flap. Int J Periodontics Restorative Dent, 35(4), 571-8.

Dutra, K. L., Longo, L., Grando, L. J., \& Rivero, E. R. C. (2019). Incidence of reactive hyperplastic lesions in the oral cavity: a 10 year retrospective study in Santa Catarina, Brazil. Brazilian Journal of Otorhinolaryngology, 85(4), 399-407.

Esmeili, T., Lozada-Nur, F., \& Epstein, J. (2005). Common benign oral soft tissue masses. Dental Clinics of North America, 49(1), 223-40.

Henriques, P. S., Okajima, L. S., Nunes, M. P., \& Montalli, V. A. (2016). Coverage root after removing peripheral ossifying fibroma: 5-year follow-up case report. Case reports in dentistry, 2016 
Research, Society and Development, v. 10, n. 2, e36710212622, 2021

(CC BY 4.0) | ISSN 2525-3409 | DOI: http://dx.doi.org/10.33448/rsd-v10i2.12622

Hutton, S. B., Haveman, K. W., Wilson, J. H., \& Gonzalez-Torres, K. E. (2016). Esthetic management of a recurrent peripheral ossifying fibroma. Clinical advances in periodontics, 6(2), 64-69.

Keskiner, I., Alkan, B. A., \& Tasdemir, Z. (2016). Free gingival grafting procedure after excisional biopsy, 12-year follow-up. European journal of dentistry, 10(3), 432.

Neville, B. (2011). Patologia oral e maxilofacial. Elsevier Brasil.

Pereira, A. S., Shitsuka, D. M., Parreira, F. J., \& Shitsuka, R. (2018). Methodology of cientific research. UFSM. https://repositorio.ufsm.br/bitstream/handle/1/15824/Lic_Computacao_Metodologia-Pesquisa- Cientifica.pdf?sequence=1\&amp;isAllowed=y

Tezci, N., Meseli, S. E., Karaduman, B., Dogan, S., \& Meric, S. H. (2015). Soft tissue reconstruction with free gingival graft technique following excision of a fibroma. Case reports in dentistry, 2015.

Walters, J. D., Will, J. K., Hatfield, R. D., Cacchillo, D. A., \& Raabe, D. A. (2001). Excision and repair of the peripheral ossifying fibroma: a report of 3 cases. Journal of periodontology, 72(7), 939-944.

Zain, R. B., \& Fei, Y. J. (1990). Fibrous lesions of the gingiva: a histopathologic analysis of 204 cases. Oral surgery, oral medicine, oral pathology, 70(4), 466470. 